\title{
10 \\ The fortified homestead of the Australian frontier
}

\author{
Nic Grguric
}

\section{Introduction}

As the Australian frontier advanced inland across the country from its coastal bridgeheads, violent collisions broke out between European settlers and Aboriginal groups. The frequency and scale of the violence varied from place to place and time to time, but one never has to look far to find examples of violence and fear between European colonists and Indigenous communities in most - if not all-geographic areas of Australia (Reynolds 2013). One of the physical traces of this frontier violence and fear can be seen in the form of what can be termed 'fortified homesteads', buildings constructed by European settlers incorporating provisions for defence against potential Aboriginal attack. Fortified homesteads represent both a real and perceived conflict between the invaders and the invaded. They are significant and unique as artefacts of the hundreds of individual wars of resistance fought by Australia's Aboriginal peoples throughout the colonial period. In 2007, the author completed doctoral research during which he explored the design, role and meaning of these structures and how these buildings can contribute to our understanding of frontier relations between European colonists and Indigenous peoples (Grguric 2007). The findings were based on four sites dating between c. 1847 and 1885, three of which are located in South Australia and one in the Northern Territory. Each of these sites had a documented story associated with them, describing them as having been built with defence against Aboriginal attack in mind. This chapter explores the association of fortified homesteads with Australian frontier conflict, both in terms of their function at the time they were built and their ongoing meaning.

\section{Frontier conflict in Australia}

The primary cause of conflict between European colonists and Aboriginal people at a grassroots level was arguably the unwitting refusal of colonists to engage in Aboriginal principles of reciprocity and, in particular, 'demand sharing', a concept introduced into the anthropological lexicon by Nicolas Peterson (1997:171-190). Demand sharing is a practice in which it is socially acceptable to demand food or items from another, as opposed to unsolicited generosity (Altman 2011:188). Peterson believes that demand sharing was widespread throughout Aboriginal society, as well as among hunter-gatherers more generally (Altman 2011:188; Peterson 1997:173). In its most simplistic form, it has a resemblance to what Nicholas Blurton Jones called 'tolerated theft' (Peterson 1997:173). 
The problem with the attempts of Aboriginal people to impart the concept of demand sharing upon European settlers was how fundamentally it conflicted with the Western view of generosity. In Aboriginal/European interactions, Aboriginal people commonly expressed it by demanding food and property from colonists and taking their seemingly plentiful livestock at will, such as when in the 1840s the house of Adelaide farmer Thomas Dyke was 'besieged' by Aboriginal people demanding flour and other goods, or when a party of 30 to 40 Aboriginal people en route to Encounter Bay in South Australia 'threatened' women in a farmhouse if they did not hand over flour (Dolling 1981:5, 33). Aboriginal people naturally felt entitled to demand such things in return for the settlers occupying their land, hunting the native game, exploiting their water sources and, all too frequently, their women (Conor 2016:14). To the settler, however, this behaviour was seen as brazen and considered pure theft.

When the colonists inevitably refused to yield their food and property, the breakdown in relations generally turned to violence in one of two ways: either the colonists, full of indignation, threatened or became violent towards the demanders, such as when young Frank Hawson flourished a gun at a group of Aboriginal people demanding food from his father's hut (for which he was speared in retaliation) (Eyre 1964 (1845):163-165), or the latter, irked by the settlers' rudeness in their refusal to conform with the laws of reciprocity, sought vengeance upon the settlers, often by plundering settler's huts, taking large numbers of their sheep by force and spearing the defenders if they resisted, such as happened on South Australia's Eyre Peninsula in the late 1840s (Police Commissioner 1848a, 1848b). Then erupted a state of animosity between the settlers and the Aboriginal people, which was expressed in wariness and tit for tat acts of violence between the two. The two sides were at war. These violent acts then escalated, with spearings of settlers becoming more frequent and economic warfare waged upon the settlers by the driving off and wholesale killing of livestock (such as when South Australian squatter John Gifford had 40 head of cattle speared in one raid in 1847) (Police Commissioner 1848c).

Settlers often dealt with the financial threat caused by this economic warfare with violence, such as when John Cox of Port Fairy in Victoria tracked down his stolen flock and found 100 ewes with their legs dislocated (a traditional Aboriginal method of keeping captured game alive and 'fresh', yet immobile). In a rage he opened fire:

It was the first time I had ever levelled my gun at my fellow man. I did so with no regret or hesitation in this instance ... I distinctly remember knocking over three ... two men and a boy, with one discharge of my double barrel. (McKernan and Browne 1988:103)

All-consuming fear and anger brought about by commercial loss of livestock and other property gave rise to that characteristic of the Australian frontier: the punitive raid. The mounting of such a raid usually marked the end of Aboriginal resistance in that particular locality, which speaks volumes for the devastating effect such raids had on the local Aboriginal population. The following excerpt from the letters of early Port Phillip squatter David Henry Wilsone provides a rarely written insight into the typical attitude and thought process of someone premeditating a punitive raid, in order to put an end to Aboriginal resistance once and for all via violent decimation of the local community:

I expect that we will have a regular fight with the natives as they are becoming very troublesome \& bold; the fools of protectors have informed them that we dare not meddle with them, or if we did we would be hanged, they stole from us five fine ewe lambs $\&$ since then all our servants are armed and are advised to shoot any one [sic] they see attempt it again or touch them, we are well off by many around us, \& soon a regular affair will settle the business and clear our part of the country of these regular cannibals [emphasis from original document]. (Serle 1977:57) 
In the harsh environment of the Australian frontier, humanitarian ideals usually gave way to self-interest. Far from the eyes of police, wives, teachers or missionaries, the station men were answerable only to themselves and the speculator back in town. This 'freedom' from the moderating influences of 'civilised' society gave vent to attitudes and acts that would have been considered unacceptable away from the frontier. And yet, those same settlers who perpetrated violent acts upon the Aboriginal inhabitants hypocritically considered themselves racially and morally superior to their victims (Serle 1977:57). This is evident in the fact that over and over again, settlers were prepared to kill Aboriginal people for stealing livestock.

Distrust of the Aboriginal inhabitants around them was a common feeling among Australian frontier settlers throughout the colonial period. This was to a large extent caused by the very different ideas of how to carry out warfare on the part of Europeans and Aboriginal peoples. The style of frontier warfare in Australia represented a greater break with tradition for the European than the Aboriginal warrior. The British notion of colonial warfare at this time was one of large forces of 'native' warriors who would attack en masse, generally dashing themselves against firearms. However, Australian frontier warfare involved fast-moving raids and ambushes. The tactics used by Aboriginal warriors was a cause of acute frustration to the settlers, essentially guerrilla warfare, naturally suited to the relatively small, independent tribal group. Traditional Aboriginal warfare was highly localised and ritualised. Its tactics consisted of ambushes and night raids, as well as pitched battles (McKernan and Browne 1988:109-110). In Aboriginal culture, these tactics were an acceptable and traditional form of fighting. To the Europeans, however, ambushes and night raids were viewed as 'treacherous' and created a sense of baffled deflation and anger at an elusive target that would not stand still for the firearm to do its work (Denholm 1979:35; McKernan and Browne 1988:110). Tactics such as these would no doubt have imposed a great psychological strain upon the minds of Europeans unaccustomed to them, especially since the brunt of frontier conflict was overwhelmingly borne by civilian settlers unused to war, rather than police or soldiers (Kerkhove 2015:9-11). Frustration at Aboriginal tactics led to the accumulation of a suppressed rage, stirring a desire to reassert superiority and self-respect by whatever means necessary (Denholm 1979:35). Settler fear was heightened in this oppressive atmosphere of distrust and misunderstanding, where one never knew when a spear might come silently flying through a window or doorway, or from the bushes (McKernan and Browne 1988:113).

\section{Enter the fortified homestead}

One of the methods settlers adopted in response to fear of Aboriginal attacks and to protect their lives and property was to fortify their buildings. This is not a purely Australian frontier phenomenon, and examples can be found in most, if not all, frontier contexts, from seventeenth-century Ireland and the United States (Blair St George 1990) to nineteenth-century South Africa (Winer 2001) and Australia (Grguric 2008:60). More recently, Burke et al. and Kerkhove have explored the design and use of fortified buildings on the Queensland frontiers (Burke et al. 2017:151-176; Kerkhove 2015:2-3).

As to the need for such fortification, there is ample evidence for Aboriginal attacks against buildings on the Australian frontier, even featuring in that classic of Australian literature, Mary Durack's Kings in grass castles, where following an Aboriginal raid on a hut, Cobby, 'Mr Durack's boy', 'insisted on firing at intervals through a hole in the wall' every night until Mr Durack returned (Durack 1997:87, 115). By way of example, in South Australia and the Northern Territory alone, the Police Commissioner's reports and the Adelaide press contained at least 27 separate cases of rural settlers being attacked, or directly threatened with attack, in their dwellings between 1842 and 1851 (Grguric 2008:78-79). References to fortified buildings on the Australian frontier are also plentiful in the historical literature, as shown in the by no means 
exhaustive table below, to which many more examples could no doubt be added (Table 10.1). Writing of the Queensland frontier, Kerkhove argues that defensive architecture was in fact the norm rather than the exception (Kerkhove 2015:8).

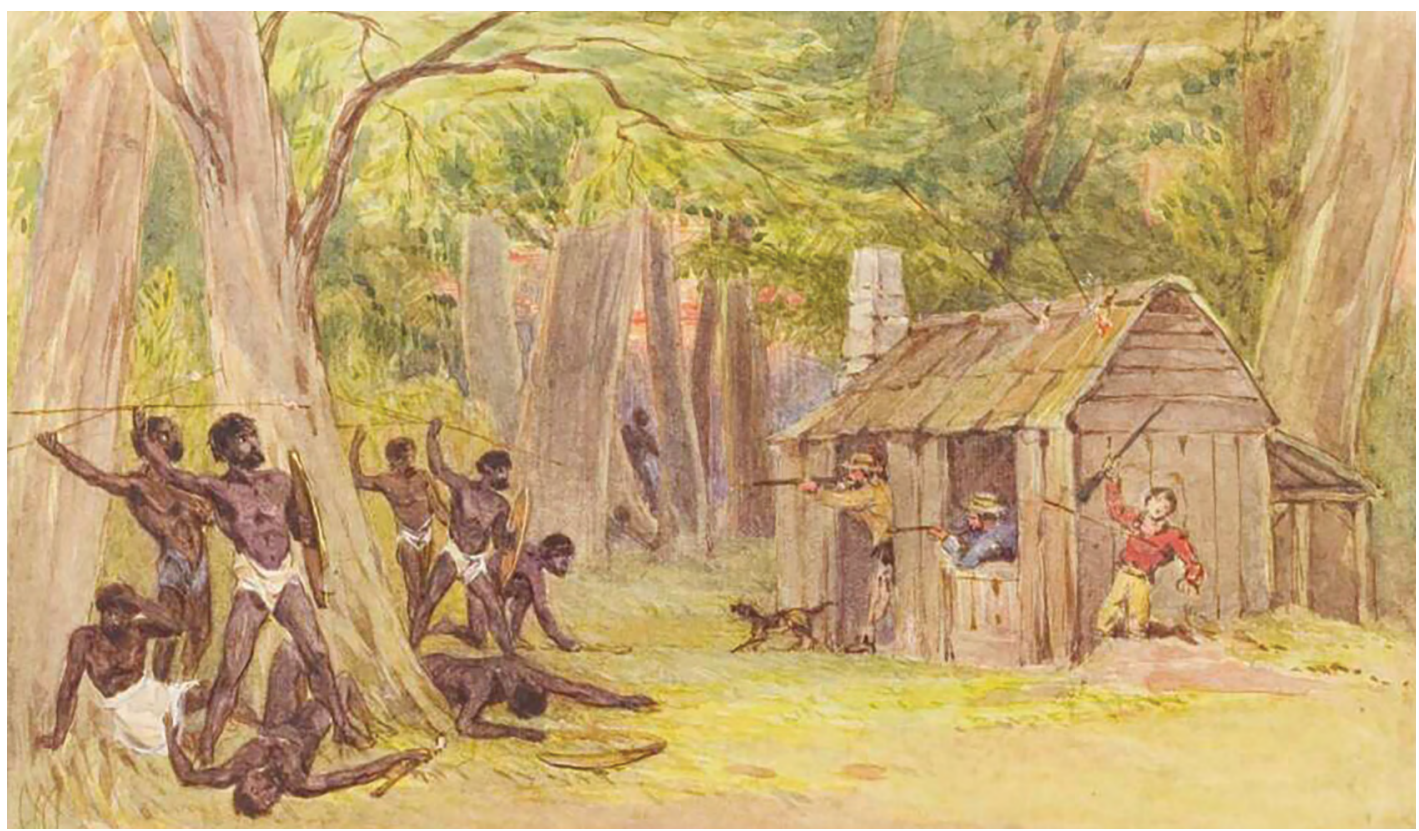

Figure 10.1. Attack on a settler's hut.

Source: James Bonwick (186-). nla.gov.au/nla.obj-135224743.

Table 10.1. Textual references to the use of defensive architecture on the Australian frontier.

\begin{tabular}{|l|l|l|}
\hline Summary of reference & Site date & Source \\
\hline $\begin{array}{l}\text { (QLD) Huts built in square formation with windows facing } \\
\text { inwards, outer walls with 'portholes'. }\end{array}$ & 1839 & Reynolds 1987:13-14. \\
\hline (VIC) Hut loopholed for musketry. & $?$ & Reynolds 1987:15. \\
\hline $\begin{array}{l}\text { (QLD) Twelve square 'portholes' cut into building's walls and } \\
\text { a gun and ammunition hung by each one. }\end{array}$ & $?$ & Reynolds 1987:15. \\
\hline $\begin{array}{l}\text { (TAS) Hut built with 'portholes' to fire out of. Roof barked and } \\
\text { covered with turf so as not to ignite. }\end{array}$ & c. 1824-1831 & Connor 2002:90. \\
\hline $\begin{array}{l}\text { (QLD) Description of loopholed huts. } \\
\text { (QLD) Homesteads built with loopholes for rifles. }\end{array}$ & Late 1840s & $\begin{array}{l}\text { Lack and Stafford } \\
1964: 72 .\end{array}$ \\
\hline (QLD) Log grog shanties with loopholes to withstand a siege. & Mid-1870s & $\begin{array}{l}\text { Lack and Stafford } \\
1964: 209 .\end{array}$ \\
\hline $\begin{array}{l}\text { (VIC) Dwellings built with loopholes out of fear of } \\
\text { Aboriginal attacks. }\end{array}$ & $\begin{array}{l}\text { Late } \\
1830 \text { s-1840s }\end{array}$ & Clark 1995:2. \\
\hline $\begin{array}{l}\text { (TAS) House with two towers loopholed for gunfire against } \\
\text { bushrangers or Aboriginal attack. }\end{array}$ & c. 1818 & Halls 1997:87-88. \\
\hline $\begin{array}{l}\text { (SA) Two-storeyed building of South Australia Company, } \\
\text { its walls with loopholes against Aboriginal attack. }\end{array}$ & c. 1840s-1850s & Dolling 1981:213. \\
\hline $\begin{array}{l}\text { (SA) Coach-house refuge, loopholed as a precaution against } \\
\text { Aboriginal attack. }\end{array}$ & c. 1852 & Dolling 1981:323. \\
\hline $\begin{array}{l}\text { (VIC) Huts loopholed to enfilade each other. } \\
\text { (QLD) Mentions that homesteads contained loopholes in walls } \\
\text { for rifles. }\end{array}$ & 1850 s-1860s & $\begin{array}{l}\text { Robinson and York } \\
1977: 43 .\end{array}$ \\
\hline $\begin{array}{l}\text { (NT) Telegraph stations built as forts with loopholes. } \\
\text { (NT) Telegraph stations with barred windows and loopholes. }\end{array}$ & Early 1870s & $\begin{array}{l}\text { Robinson and York } \\
1977: 96 .\end{array}$ \\
Mulvaney 1989:119. \\
\hline
\end{tabular}




\begin{tabular}{|c|c|c|}
\hline Summary of reference & Site date & Source \\
\hline (QLD) Description of ‘Rainworth Fort' as defensively constructed. & 1862 & Mulvaney 1989:103. \\
\hline $\begin{array}{l}\text { (QLD) Description of a home being made more secure } \\
\text { against attack. }\end{array}$ & $?$ & Fysh 1933:99. \\
\hline $\begin{array}{l}\text { (QLD) Homestead's doors loopholed to accommodate rifles in } \\
\text { case of Aboriginal raids. }\end{array}$ & $?$ & Fysh 1933:126. \\
\hline (QLD) Log hut with loopholes. & 1888 & Fysh 1933:191. \\
\hline $\begin{array}{l}\text { (NSW) Angled slit in a dwelling's wall thought to be an } \\
\text { embrasure for dealing with intruders. }\end{array}$ & 1840s (?) & Cantlon 1981:46. \\
\hline $\begin{array}{l}\text { (NSW) Hut with embrasures in corners and sides of walls, with } \\
\text { hinged wooden shutters which could be opened to fire through. }\end{array}$ & 1845 & Cantlon 1981:124. \\
\hline $\begin{array}{l}\text { (NSW) Homestead with large flat-roofed tower with 'portholes' } \\
\text { was used as a lookout. Sentry posted to warn of approach. } \\
\text { Building also had an armoury. }\end{array}$ & $1888-1891$ & Croft 1965:29, 31. \\
\hline $\begin{array}{l}\text { (NT) Outbuilding's upper-level apertures in walls thought to be } \\
\text { embrasures for defence against attack. }\end{array}$ & 1885 & Norris 1976:78-79. \\
\hline $\begin{array}{l}\text { (NT) Telegraph station with enclosed courtyard and } \\
\text { embrasures. }\end{array}$ & $1873(?)$ & Norris $1976: 80-81$. \\
\hline (NT) Telegraph station with enclosed courtyard and embrasures. & 1871 & Norris 1976:82-83. \\
\hline $\begin{array}{l}\text { (TAS) Homestead with high brick enclosing wall with firing } \\
\text { positions. }\end{array}$ & $\begin{array}{l}\text { Late } \\
1820 \text { s-1830s }\end{array}$ & Ryan 1996:104. \\
\hline (SA) Homestead dwelling with rifle 'porthole'. & Late 1840 s & Barrowman 1971:52. \\
\hline $\begin{array}{l}\text { (SA) Door from station outbuilding with aperture to permit use } \\
\text { of a rifle. }\end{array}$ & Late 1840 s (?) & Barrowman 1971:52. \\
\hline $\begin{array}{l}\text { (SA) Door from station outbuilding with embrasure for } \\
\text { discharge of firearm. }\end{array}$ & Late 1840 s (?) & Banks 1970:8. \\
\hline (SA) Rifle ‘loophole’ in men’s hut on station. & $?$ & Baillie 1978:134. \\
\hline (SA) Building's tiny ‘windows' built as protection against attack. & Late 1840 s & Baillie 1978:134. \\
\hline $\begin{array}{l}\text { (SA) Dwelling with 'attic retreat' with apertures for rifle fire } \\
\text { against attack. }\end{array}$ & 1840s (?) & Baillie 1972:20. \\
\hline (QLD) Log homestead built like a fort with loopholes. & c. 1860 & Pike 1978:104-105. \\
\hline (VIC) Huts built with loopholes. & c. $1840 \mathrm{~s}$ & $\begin{array}{l}\text { McKernan and Browne } \\
\text { 1988:103. }\end{array}$ \\
\hline $\begin{array}{l}\text { (VIC) Huts built like forts with slotted windows for firing } \\
\text { through. Settlers using cannon. }\end{array}$ & 1840 s (?) & Broome 2005:72. \\
\hline $\begin{array}{l}\text { (QLD \& VIC) Homesteads built with shutters rather than } \\
\text { windows for defence and inward facing homestead layouts. }\end{array}$ & $?$ & Cannon 1973:30. \\
\hline $\begin{array}{l}\text { (QLD) Loopholed civilian fort at Bertiehaugh station fitted with } \\
\text { a swivel gun. }\end{array}$ & 1887 & Pike 1978:165. \\
\hline $\begin{array}{l}\text { (General) Settlers preferred to build atop high creek banks as } \\
\text { defence against Aboriginal attack. }\end{array}$ & $?$ & Taylor 1988:24. \\
\hline $\begin{array}{l}\text { (VIC) Contemporary squatter describes huts as loopholed } \\
\text { to enfilade each other. }\end{array}$ & $1830 \mathrm{~s}$ & Taylor 1988:65. \\
\hline (WA) Lillimooloora station described as fortified. & 1884 & $\begin{array}{l}\text { Pedersen and } \\
\text { Woorunmurra 1995:155. }\end{array}$ \\
\hline (WA) Makeshift barricades erected at Noonkanbah station. & 1896 & $\begin{array}{l}\text { Pedersen and } \\
\text { Woorunmurra 1995:159. }\end{array}$ \\
\hline (WA) Fortress-style construction of Oscar Range station. & 1896 & $\begin{array}{l}\text { Pedersen and } \\
\text { Woorunmurra 1995:182. }\end{array}$ \\
\hline $\begin{array}{l}\text { (VIC) Log hut with loopholes to defend against superior } \\
\text { numbers of Aboriginal attackers. }\end{array}$ & 1840 & $\begin{array}{l}\text { Gardner 1993:13, } \\
44-46 .\end{array}$ \\
\hline $\begin{array}{l}\text { (QLD) Huts built in square formation with windows facing } \\
\text { inwards, outer walls with 'portholes'. }\end{array}$ & 1839 & Armstrong 1980: 120. \\
\hline $\begin{array}{l}\text { (TAS) Dwelling with two square towers with musket slots } \\
\text { for defence. }\end{array}$ & 1820 & $\begin{array}{l}\text { Smolicz and Sharp } \\
\text { 1983:66. }\end{array}$ \\
\hline $\begin{array}{l}\text { (General) Homesteads sited on high ground, wooden shutters } \\
\text { instead of glass windows and 'gun holes' in walls for defence. }\end{array}$ & $?$ & $\begin{array}{l}\text { Cox and Stacey } \\
1972: 9,14 .\end{array}$ \\
\hline
\end{tabular}

Source: From Grguric (2007:76). 


\section{Identifying fortified homesteads}

When it comes to extant buildings, actually differentiating between those architectural features associated with defence and those of a peaceful function can be difficult. It is important that one turns a very measured eye on such features in order to avoid forming a false association between a structure and the sensitive topic of frontier conflict. One can go too far in either direction: on the one hand, being too quick to dismiss the possibility of fortification, thereby (unwittingly or not) playing into the 'empty frontier' narrative and denying Aboriginal resistance its agency. On the other hand, if one is too ready to ascribe a defensive function to buildings, one has the potential to create false evidence of frontier conflict, or at least the fear of European colonists, thereby providing ammunition for frontier conflict deniers to level charges of fabricating data upon researchers of frontier conflict.

A limiting factor for the identification and study of extant fortified homesteads is they need to be in a suitably good state of preservation so that any defensive features are still in situ. In most cases, the key diagnostic feature is the presence of one or more embrasures. The word 'embrasure' is taken from military engineering and can be defined as a small aperture in a wall, sometimes splayed out on the interior, and generally square or rectangular, although they can also be round. It is designed to allow a defender to fire weapons through while its small size renders the defender practically invulnerable to the attacker's missile weapons.

In practical terms, this generally means their walls need to be standing to a sufficient height for any embrasures to be visible. The fortified structures studied as part of the author's research into this phenomenon were generally in a good to very good state of preservation, partially attributable to the fact that they were all constructed of stone. They consisted of a squatter's dwelling built c. 1847 in the south-east of South Australia; a farmer's coach-house in what is now Adelaide's southern suburbs, built c. 1851; an accommodation building for workers on a sheep run on the Eyre Peninsula of South Australia built c. 1856; and a dwelling built c. 1879 and store built c. 1885 at a pastoral station near Katherine, in the Northern Territory.

\section{Vernacular architecture in frontier Australia}

The confusion that surrounds civilian use of defensive architecture stems from the dual purpose nature of these sites. Such buildings were not usually purely defensive structures like a fort (although a notable exception in Australia are the civilian-built 'shielans' of Queensland, which were structures built deliberately as defensible refuges in event of an Aboriginal attack), but instead they served primarily as dwellings or outbuildings and secondarily as defensive structures. Sometimes even the non-defensive functions of these structures are unclear or unknown. Therefore, what would usually be a typical diagnostic element of fortification, such as a narrow slit in a wall, may have served an entirely different purpose, such as for ventilation. This issue is not restricted to the Australian context; studies of civilian defensive architecture elsewhere have grappled with the same problem. For example, Blair St George, in his investigation of the Whitfield House, a seventeenth-century house in Connecticut, USA, found that there was disagreement over the existence and function of what he argues was a cannon embrasure-a small opening designed to discharge weapons-located in an upper wall of the house (Blair St George 1990:265). Blair St George convincingly argued that it was in fact a cannon embrasure. One of the ways he supported his interpretation was by comparing it to several surviving seventeenthcentury houses in England and France that have well-documented cannon and pistol embrasures (Blair St George 1990:265-266, 276-277). While there is no debate as to whether military-built forts (e.g. Crosby 1978) and civilian-built blockhouses (Roos 1953:4) are what they are (that is, functionally built defensive structures), this is not the case with Australian fortified homesteads. 
Some versions of history describe particular sites as having been built for defence, whereas others do not. By comparing the design of the structures that may have defensive features with the 'typical' (i.e. non-defensive) design of the vernacular rural architecture of the period, it is possible to observe the ways in which defensive sites were modified from the typical design.

Nineteenth-century vernacular architecture in Australia was heavily influenced by conventions that had been long established in Britain. The basic type of two-roomed country cottage (Boyd's 'primitive cottage') that influenced the colonial builders, both in town and in rural areas, dates back to the late eighteenth century, with those cottages found in the Scottish highlands and the west coast of Wales being particularly influential to the Australian vernacular styles (Boyd 1961:1; Pikusa 1986:19). The primitive cottage, in its most basic form, was characterised by one room, the living room/kitchen, being slightly longer than the other. One small window was placed either side of the door and a fireplace and chimney stood at the far end of the living room/kitchen. The side and rear walls were nearly always blind (i.e. they had no openings) (Boyd 1961:8). This is a feature of Australian vernacular cottages that comes from their British antecedents and is not a defensive feature. The reason for the lack of windows in the rear wall has its origins in the cottages of the northern hemisphere, which were generally sited so that the openings were on the southern side, protected from the prevailing northerly winds (Pikusa 1986:19-20). The same procedure for siting was followed in Australia, although the building's orientation was often altered depending on the particular direction of the prevailing wind. It appears that, both in the British and Australian cottages, the only time a rear door was included in the plan was if there were buildings at the rear of the dwelling such as a washhouse, storage shed, privy or chicken house (Pikusa 1986:23). Otherwise they were not considered necessary. Although superseded by larger houses during the second half of the nineteenth century, in rural areas the simple cellular cottage of two rooms continued to be popular well into the twentieth century (Pikusa 1986:22). This type of plan is also characterised by its additive quality. That is, its open-endedness allowed additional cells to be added to the sides or rear to suit the particular circumstances (Cox and Lucas 1978:14). Incidentally, all three of the fortified dwellings that served as case studies in the author's original research project were based on the primitive cottage plan, though in the more elaborate form of a complex of cells.

The key difference between the typical design and the examples of fortified homesteads that formed the author's case studies was the existence of one or more small embrasures located in the rear walls of the dwellings. As mentioned above, the rear walls of vernacular primitive cottages were typically blind, sometimes with the exception of a doorway. Architectural literature dealing with the design of British and Australian rural dwellings is almost always silent on the function of these apertures. One exception is The Australian homestead, which mentions that when defence against bushrangers or Indigenous peoples was needed, wooden shutters were used instead of window panes, and 'gun holes' were incorporated into the walls (Cox and Stacey 1972:14). Their absence from nearly all of the architectural literature suggests that such embrasures were evidently not a part of the usual cottage plan, either in Europe or Australia. Rather, they appear to have been incorporated if, and when, deemed necessary in response to local situations. Therefore, these embrasures would represent a key diagnostic feature of frontier defensive architecture.

\section{The role of fortified homesteads - then}

The location of embrasures suggests how these structures were designed to function in a defensive capacity. Being primarily places where people lived, it would have been undesirable and impractical to do away with conventional windows all together, and to construct conventional windows in the usually blind rear walls of the dwellings was evidently too far a departure from the vernacular. The construction of one or more embrasures in the usually blind rear wall was 
a very practical solution. It was cheap, easy to do and relatively unobtrusive, yet it allowed the occupants to observe any threats approaching from that side of the building, and to respond with firearms without exposing themselves.

A classic example of this practice can be seen in the 'men's hut' at Central Outstation in the western Eyre Peninsula, South Australia. Constructed in the 1850s, its façade bears the standard, practical vernacular arrangement of doors and windows, with a fireplace at both ends. The interior is divided into three rooms, one small room in the centre and a larger room to either side. However, its rear is where it departs from the vernacular and into frontier architecture. The rear wall is pierced by three embrasures, the surviving example being approximately $30 \mathrm{~cm}^{2}$. These embrasures were arranged so that one served each of the three rooms, and provided a means of observation and protection for the rear of the building.

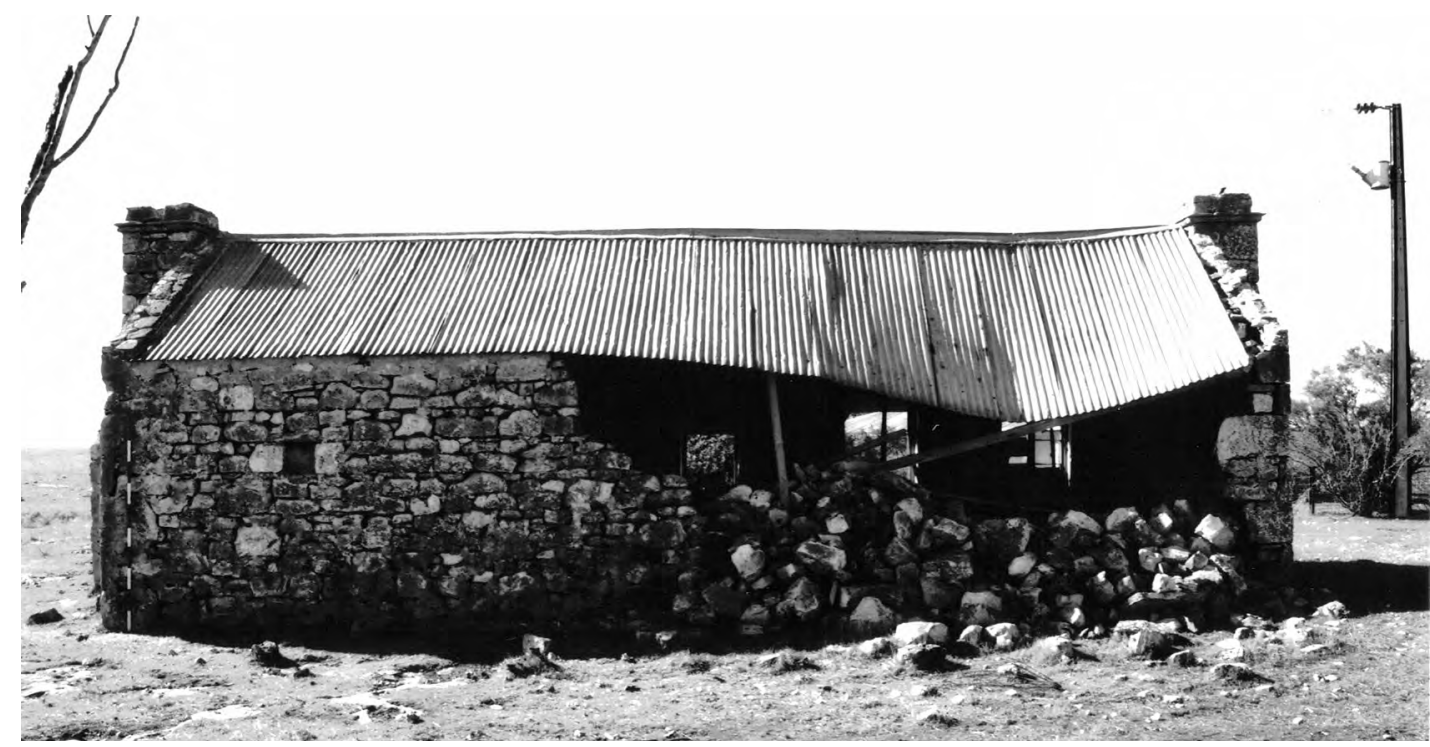

Figure 10.2. Rear view of the 'men's hut', once part of Central Outstation, a sheep run on the western Eyre Peninsula of South Australia.

There were originally three embrasures positioned along this wall, one per internal room. However, due to collapse, only one is still in situ (on the left).

Source: Nic Grguric.

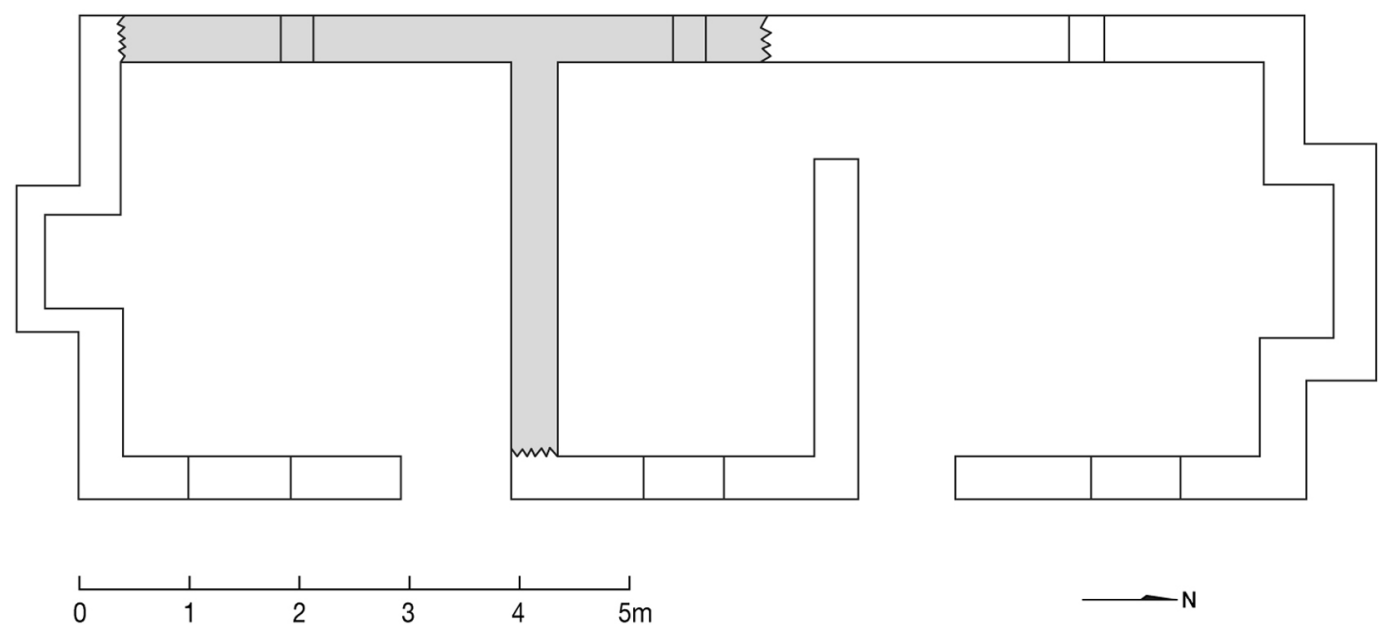

Figure 10.3. Plan view of the 'men's hut' at Central Outstation, with collapsed portions reconstructed based on physical evidence and a historical photograph.

Source: Nic Grguric; ANU CartoGIS (digitisation of plan). 


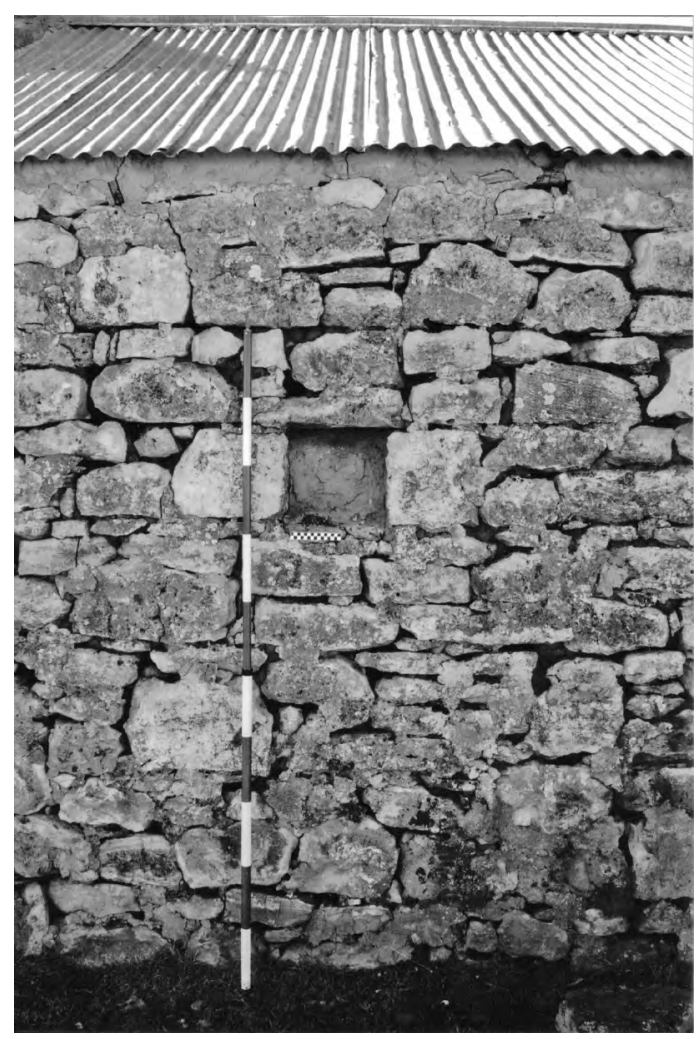

Figure 10.4. Exterior of extant embrasure in the 'men's hut' at Central Outstation, subsequently blocked up.

Source: Nic Grguric.

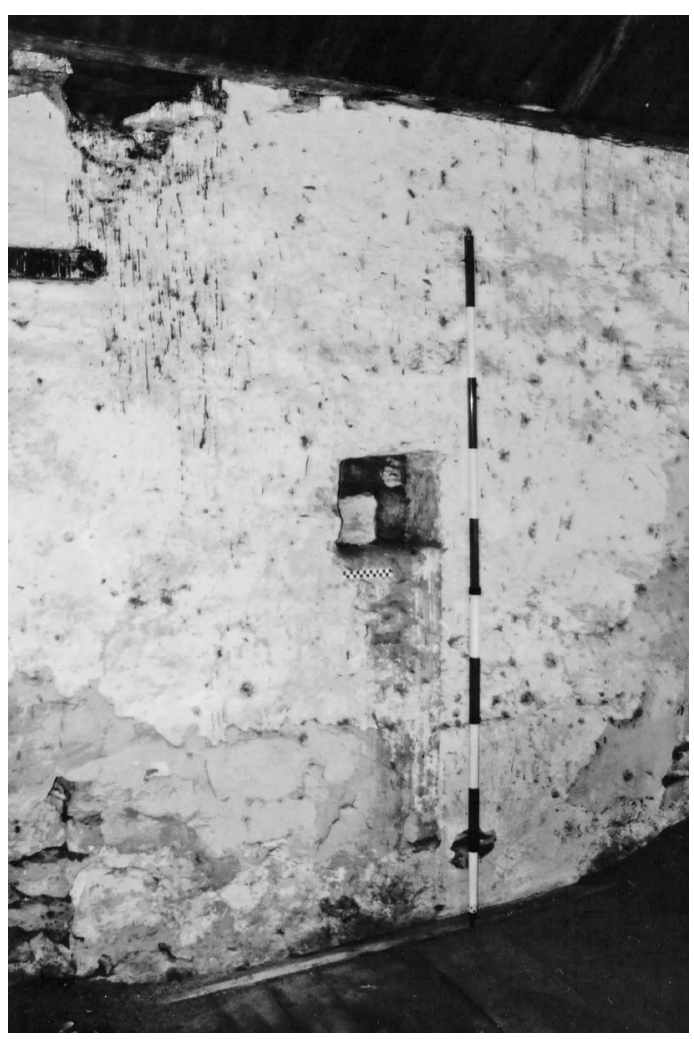

Figure 10.5. Interior of extant embrasure in the 'men's hut' at Central Outstation, subsequently blocked up.

It is positioned approximately $1.1 \mathrm{~m}$ from the floor, a convenient height for a shooting stance.

Source: Nic Grguric.

The retention of conventional windows elsewhere in the building may at first glance appear to defeat the purpose of embrasures in the rear wall—after all, it would have been just as likely that attackers would approach from the front of a building-however, it was common for frontier dwellings to have sturdy wooden shutters, sometimes pierced with an embrasure (Cannon 1973:30; Cox and Stacey 1972:14). When closed and locked, they would render a dwelling very secure from ingress of attackers and their weapons.

There is evidence that doors were also fitted with embrasures. A very rare surviving example from Keilira (originally 'Avenue Range') station in the south-east of South Australia, dating from the 1840 s or 1850 s, has a small square cut out of it at chest level with a wooden slide. The old, handwritten label attached to the door reads, "[d] oor from old "Keilira", opening specially made by James Brown for the use in many raids on the Aboriginals of his day' (from the text accompanying the door at the Kingston SE National Trust Museum, South Australia).

When it comes to outbuildings, it is even more challenging to differentiate between those apertures that were built for defence and those that were built for ventilation or other purposes. This is because the presence of apertures in outbuildings such as stables and barns are common, and in most cases not intended to serve a defensive function. In these cases, the only way to determine an outbuilding's defensive construction is through supporting evidence and/or a detailed understanding of the building's original function. 
It is possible that the apertures of some outbuildings were designed to have a dual function for ventilation and defence should the need arise. Where this is the case it becomes almost impossible to determine with confidence whether the structure was built to serve a defensive role, even as a secondary function. In such cases, all one can do is refer back to the primary documentary evidence, which may, or may not, be considered strong enough to support the interpretation of such a structure as defensive.

Such were the challenges when it came to investigating the defensive functionality of the coachhouse and store building that featured in the original research project. The following case studies are discussed below by way of examples as to the analytical process that is required to assess the defensive functionality of outbuildings.

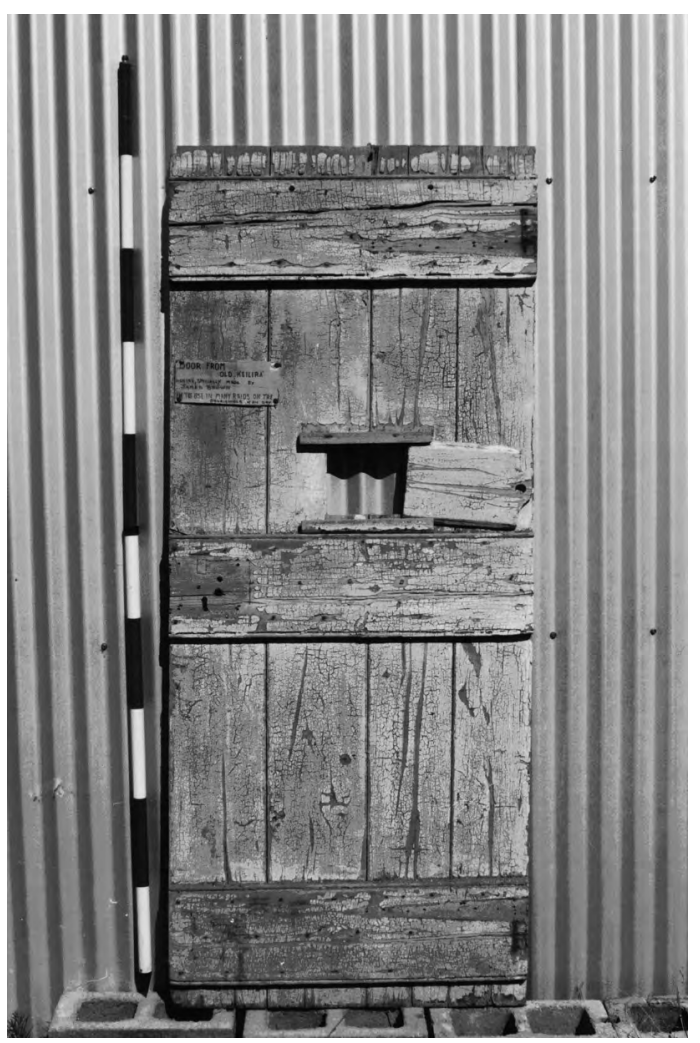

Figure 10.6. Door from 'Avenue Range' (later 'Keilira') pastoral station.

The note attached reads, 'Door from old "Keilira”, opening specially made by James Brown for the use in many raids on the Aboriginals of his day'. Although poorly worded, the label identifies the aperture as having been constructed specifically for defensive purposes.

Source: Nic Grguric.
Turning to the 'coach-house', assertions that it was simply a typical English-style bank barn (Bell 1997:10) were refuted partly on the basis that the room with the apertures, which would then have been where grain was stored if it was a bank barn, contained an open fireplace and a conventional casement window. These are features much more indicative of human habitation than crops or livestock. Documentary evidence suggests that this room may have functioned as an office for the running of the farm, with the vehicles that give the building its name being stored below in a lean-to (Grguric 2007:211-212). Further to this, the property already had a much larger barn building (and stables) at the time the coach-house was constructed in 1851 (Grguric 2007:212). That the internally outwardsplaying embrasures in the walls were for ventilation is highly unlikely, given the presence of ventilation bricks and a window. As one of its functions at least, this building appears to have been designed as a defensible refuge for those around the homestead in the event of an attack. The presence of a fireplace in the room with the apertures, as well as a loft, would make this building very well-adapted as a refuge. The hearth could have been used for warmth and for cooking, and the loft, only accessible via a ladder and trap-door, would provide a good fallback position or safe area for women and children. This building was also positioned in the centre of the homestead complex, retaining clear fields of fire and vision on the embrasured sides. This central positioning was possibly designed to allow it to be the same distance from either end of the homestead complex, so that wherever one was at the time of the threat, the refuge was not too far away. 


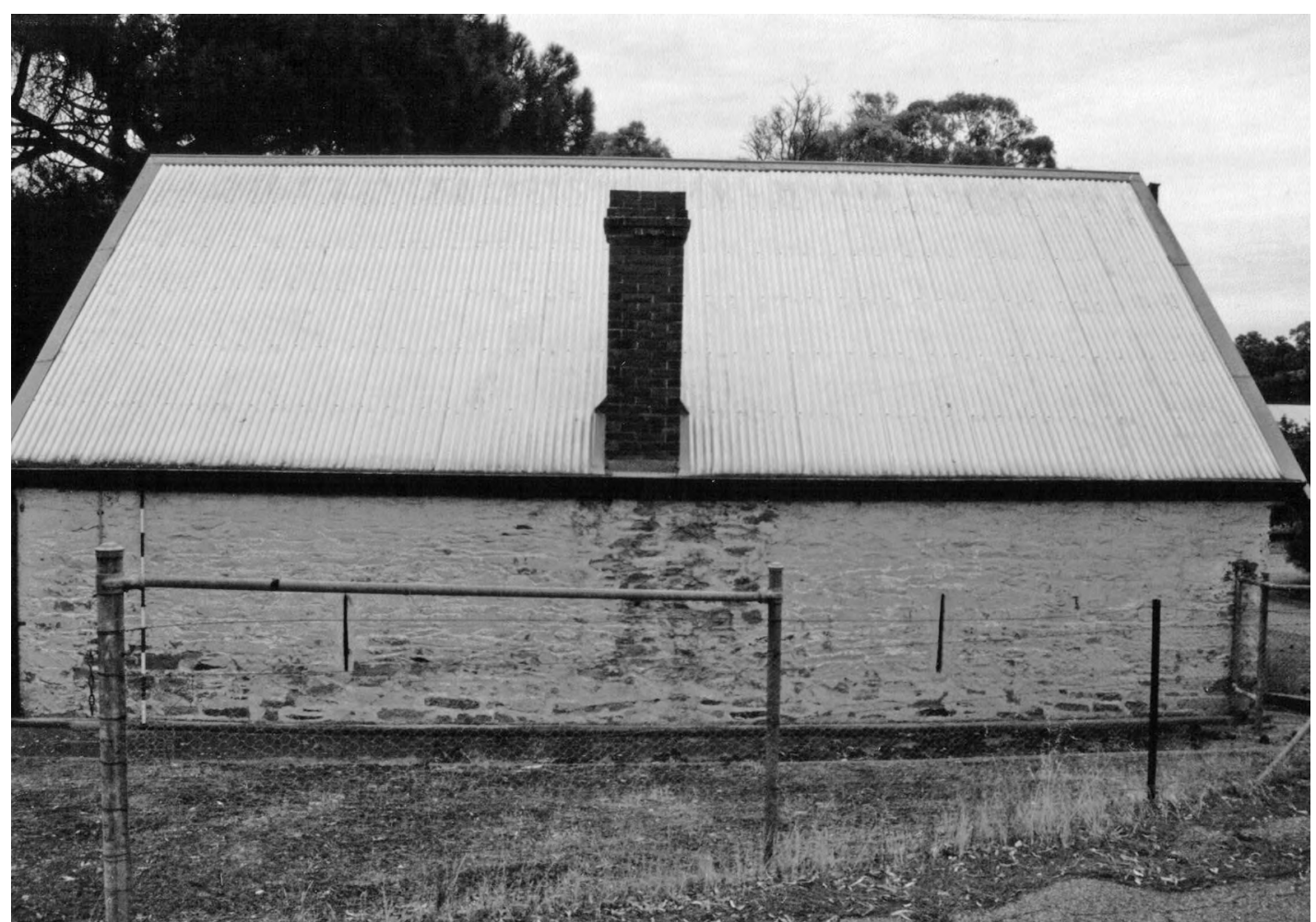

Figure 10.7. Eastern aspect of the 'coach-house' at the site of Lizard Lodge, once a semi-remote farm, now in suburban Adelaide.

Two of the narrow vertical embrasures are visible. These splay out on the interior, allowing greater visibility and traversal of firearms, thereby greatly increasing the field of fire.

Source: Nic Grguric.
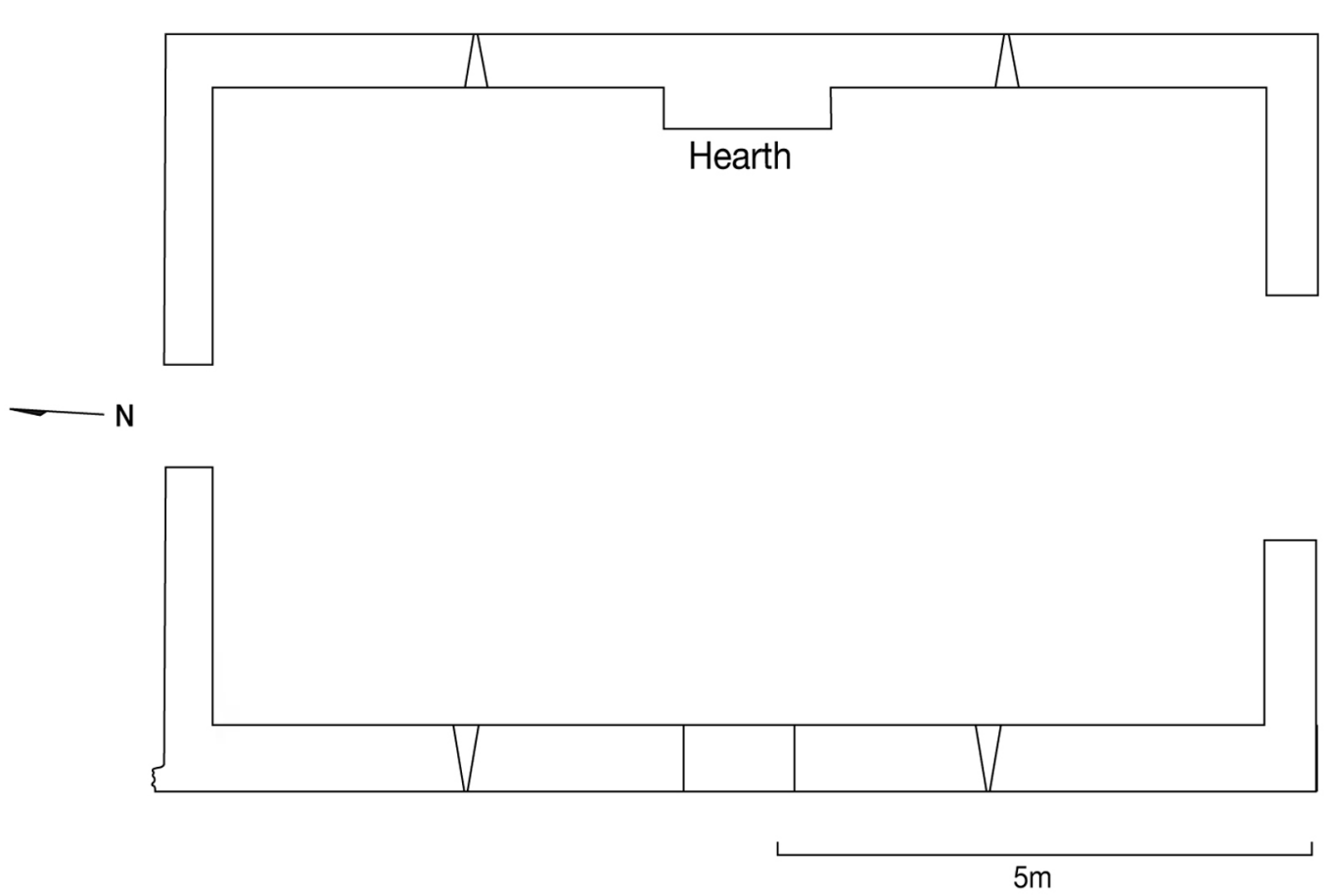

Figure 10.8. Plan of the 'coach-house' at the site of Lizard Lodge showing the position of the internally splayed embrasures in relation to the fireplace and conventional casement window. Source: Nic Grguric; ANU CartoGIS (digitisation of plan). 


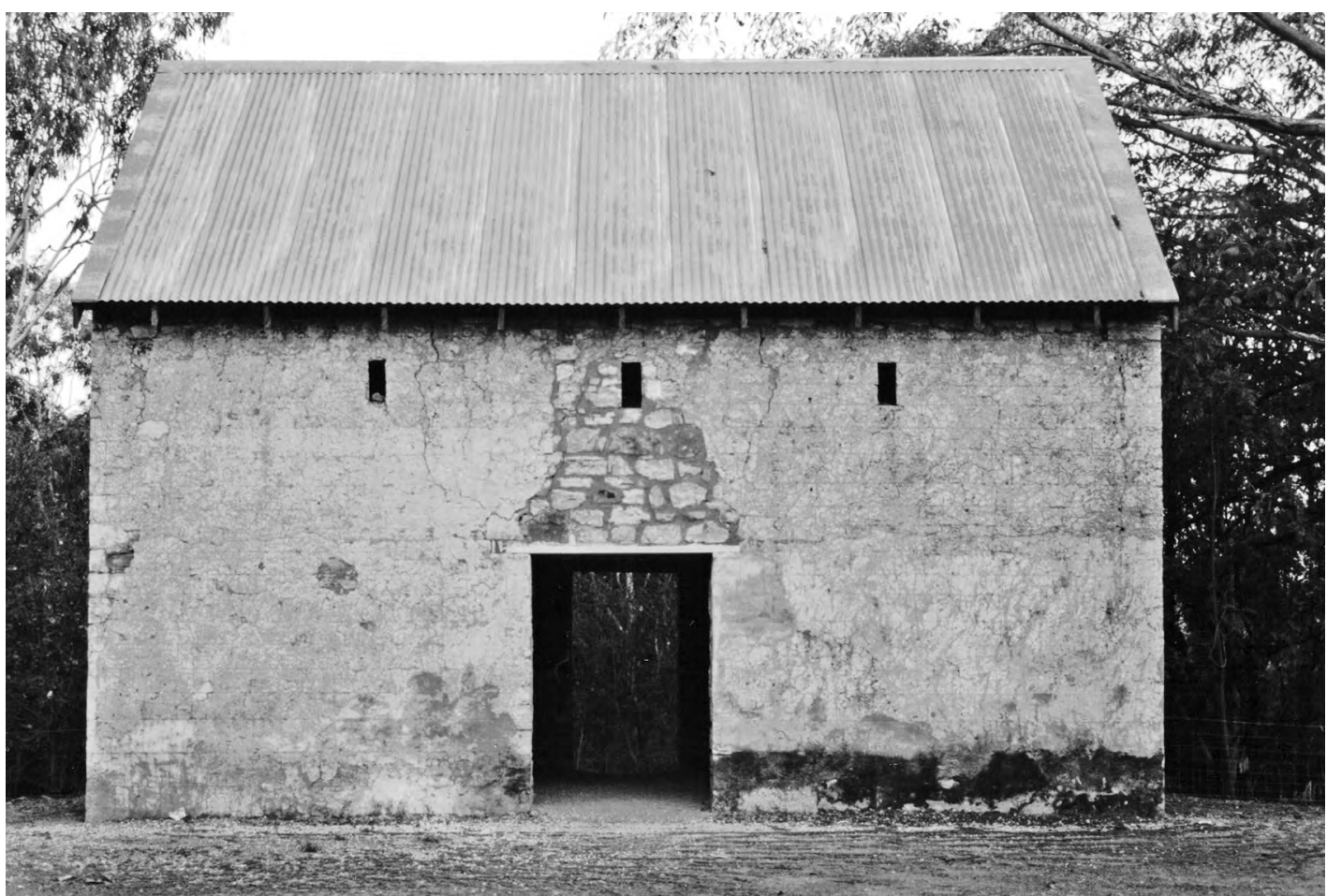

Figure 10.9. Western elevation of 'the Old Fort' store building at the former site of Springvale Station, near Katherine, Northern Territory.

Showing the embrasures that pierce all sides of the upper level. Also note the absence of windows on the ground level.

Source: Nic Grguric.

The store at Springvale homestead was designed primarily for use as a store; however, at times, it has been popularly known as 'the Old Fort' or simply 'the Fort' (Allom 1980:1.0). It is evident that the embrasures doubled as ventilation apertures, since two of them would have been inaccessible for firing through; however, that it was designed to be functional as a defensive structure is evident from its overall secure design, with no windows in the ground floor, yet with accessible apertures that could function as embrasures around all four sides of the loft, and no windows. It seems most likely that the tactical role of the store was for it to be 'garrisoned' in order to defend its contents, in the event of an attack upon the homestead.

Springvale Station is not the only known site of an extant fortified store in Australia. Another, earlier example exists, known as 'Rainworth Fort' near Springsure in Queensland, built in 1862. Like that at Springvale, Rainworth Fort was built as a station store, with an upper storey whose walls were pierced on all sides with embrasures to serve as a defensive structure in the event of Aboriginal attack.

\section{Firearms and fortified homesteads}

Practical investigations into the capabilities of the typical firearms available to settlers on the Australian frontier indicated there was no evidence for an association between advances in firearms technology and changes to defensive architectural techniques (Grguric 2007:310-340). This is worth noting, though perhaps not surprising, even given the great advantage to firearms capability provided by the widespread adoption of breechloading firearms from the 1870 s. Faster-firing and longer-ranged firearms did not render defensive architecture obsolete. This may 
have less to do with the capability of these firearms than with the nature of Aboriginal homestead attacks. The primary accounts that describe such attacks give the impression that the Aboriginal attackers were usually able to stealthily approach quite close to a building before the occupants were either aware of their presence or intention, thereby negating the increased accuracy of the later firearms at longer ranges.

\section{The role of fortified homesteads - now}

When the frontier had moved comfortably away from their location and the passage of time had consigned those desperate days to history, some of these fortified homesteads became items of historical interest and part of local lore. Stories were told that were sometimes recorded in local history books, specifically drawing attention to their having been fortified as a defence against Aboriginal attack. These stories constitute interpretations of the architecture just as much as purely material culture-based interpretations do. Likewise, such interpretations are sometimes disputed. A common method used by those who dispute the defensive interpretation of a particular frontier building is to omit of any mention of this interpretation, rather than putting forth their case why it was not so. Examples of this were found in literature dealing with two of the sites that served as case studies in the author's original research project: the coachhouse in Adelaide's southern suburbs (Bell 1997) and the dwelling and store at Springvale Station near Katherine in the Northern Territory (Forrest 1985).

By way of example, Peter Forrest's Springuale's story (1985) provides a prime example of the way local histories can create an exclusionary past by omitting mention of fortification and frontier conflict. This is the only published local history of the Springvale site and, as such, represents the definitive history of Springvale. This must be a deliberate omission, considering that 21 of the book's 73 pages deal with Alfred Giles's overland expedition to establish the station, Giles having been the builder of the structures in question. Giles's own account of the expedition describes several confrontations with Indigenous people, including several violent clashes that ended in fatalities (Giles 1870-1885:35-36, 39, 106). Forrest must have known about these incidents, since the manuscript in which they are found appears in his bibliography.

Turning to the homestead of Springvale itself, Forrest makes no mention whatsoever of the defensive function of the store building known as 'the Old Fort' (Allom 1980). Nor does he explain the function of the two round apertures built into the stonework on either side of the homestead's rear door, even though Giles's own son mentions them as having been built for defence (Giles n.d.:10). In doing so, Forrest contributes to the creation of a sanitised frontier where Aboriginal resistance has been painted out of the picture.

Haggis notes that:

local history is not to be trusted because rural communities put a great deal of effort into covering up a past of violence and expropriation that was often uncomfortably recent in terms of family and community memory. (Haggis 2001:92)

Conversely, Foster, Hosking and Nettelbeck believe that this silence on frontier conflict is less true of local histories because they are the product of informed local history knowledge and completely at odds with the received wisdom of a twentieth century white historical silence' (Foster et al. 2001:9). While at first glance these two views appear opposed, both can actually be true within the context of one building, and both tie in to settler identity construction and social memory. 

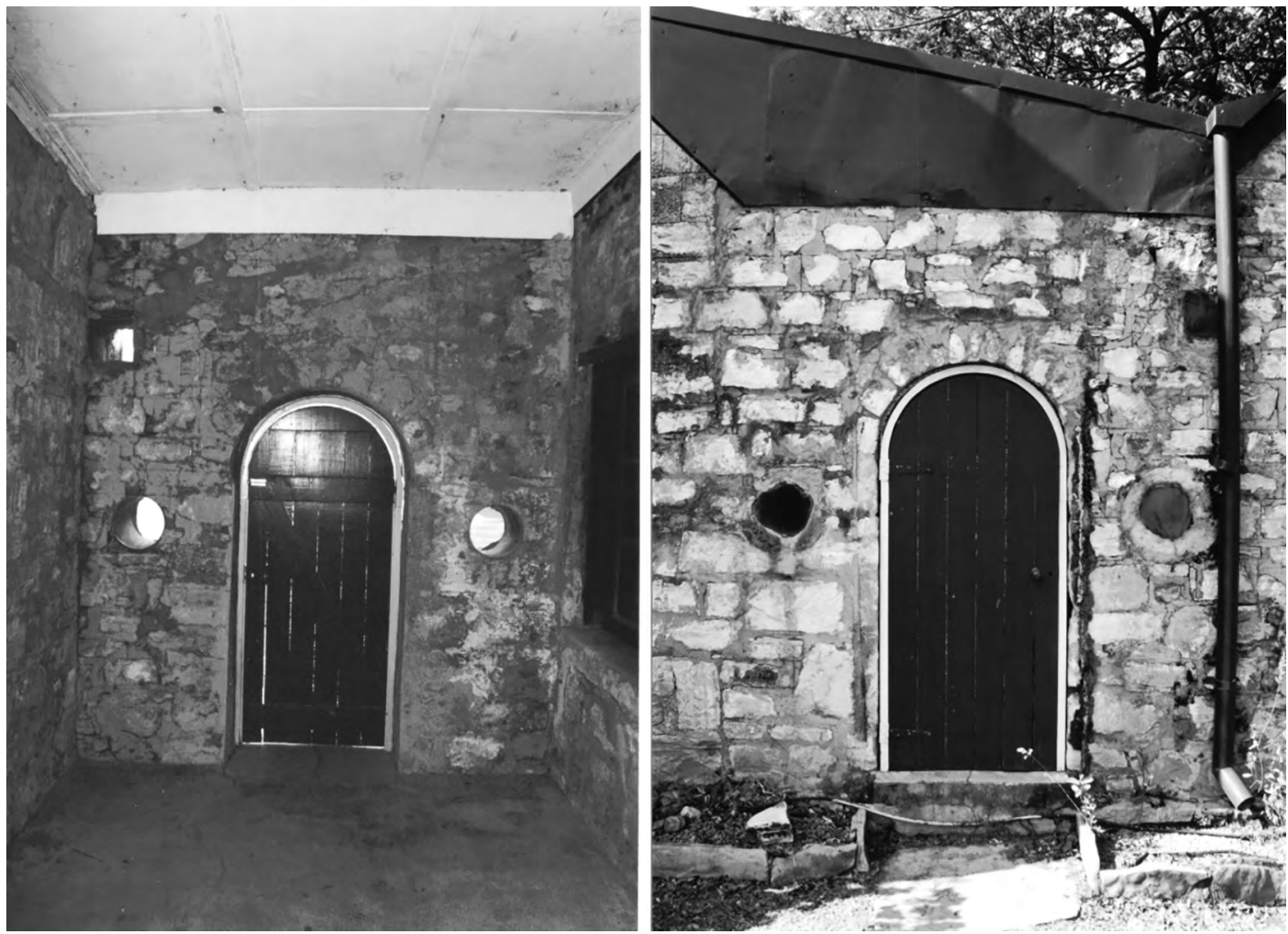

Figure 10.10. Interior (left) and exterior (right) of the circular embrasures either side of the rear door of Springvale homestead.

These are the features described by the builder's son, Harold Giles, who lived there in his childhood, as having been 'built in case of danger from blacks attacking' (Giles n.d.).

Source: Photograph by Nic Grguric.

Rather than omitting all mention of fortification and frontier conflict, those accounts that do highlight the defensive construction of frontier buildings usually frame it in such a way that it mythologises the settler. Many fortified frontier buildings have, through their associated stories, thus evolved in their meaning to become just as much monuments as statues. Monuments are meant to create consensus and stability and the durability of landscape and the monuments placed in it makes them effective symbols for the sustaining of values over long periods (Foote 1997:33). This is the role that fortified homesteads often play in contemporary settler society.

While in a way acknowledging a prior Aboriginal presence on the land, such stories of fortified homesteads serve to portray the settler as a victim of violent 'savages', intent on murdering the settler in his or her own home. In this light, the Aboriginal threat is portrayed as just one of a series of challenges the settler had to overcome in order to conquer and civilise the bush. Settler societies are notorious for developing such 'narratives of reversal' when it comes to dealing with frontier conflict, where Indigenous people are portrayed as the invaders and the settlers as the defenders (Curthoys 2003:193). The customisation of the frontier and Indigenous people by settler societies for their own ideological use has been discussed both in the United States, by archaeologist Patricia Rubertone, and in Australia, by historian Richard Broome, among others (Broome 1996:55; Rubertone 1994:34). Rubertone also demonstrated the important fact that archaeology has the potential to redress this situation, and thereby provide different interpretations of Indigenous history, and in particular Indigenous responses to colonialism that are often unrecorded in written sources (Rubertone 1994:32). Stories associated with fortified homesteads are typically framed in terms of the need for settlers to defend themselves against 
Aboriginal attack, while no mention is made of the latter's motives for attack. 'Their [i.e. the Indigenous people's] history of the event has been overlooked, because it serves Euro-American [or Euro-Australian] needs to dehumanise [them] and justify conquest' (Shakel 2001:4). This one-sided portrayal of frontier conflict leads the average receiver to regard the aggressive actions of Aboriginal resistance as that of savages. To omit Aboriginal grievances but highlight their violent response has served an important role in contemporary settler identity construction, that of removing settler guilt. Furthermore, this reversal of roles, casting the Indigenous defender as aggressor and the invading colonist as defender, also serves the very important purpose of constructing a past that 'allocates the land as won through suffering, and therefore as theirs ... the self-chosen white victim finds it extremely difficult to recognise what he or she has done to others' (Curthoys 2003:199). This is precisely what settler identity construction has traditionally been designed to do, since it serves to turn people's minds away from the dark truths of the foundations of their society and keep people proud of their whiteness and the community that it forged.

These sites tell us that, for both sides, the frontier was a place of open conflict and fear. Fear of Aboriginal attack may have caused the settlers to fortify their buildings, but this very specific fear of attack was only one aspect of the general atmosphere of fear that pervaded the lives of both sides. The particularly strong nature of the fear is reflected in the fact that it caused the builders to modify long-established vernacular construction techniques in order to help address it.

The existence of these civilian-built structures also speaks volumes about the lack of protection afforded to settlers by the government in the form of the police and military. The government was often either unwilling, unable or particularly poor at preventing frontier conflict, and the settlers evidently did not consider that they could rely on the government for protection. This message comes out very clearly in the following quote by squatter Dr Wilsone, where he complains of:

the disgraceful manner we have been treated by the Governor of N.S. Wales \& Protectors of the Blacks, a parcel of regular humbugs; in fact we are left totally unprotected, when we have paid so dearly to have been so by mounted police, \& the consequence must rest on their heads, as we have all united to defend to the utmost our properties \& woe betide the blasted race when they are caught injuring us. (Serle 1977:61, emphasis in original)

This shows that often the civilian settler really was the frontline agent of colonial invasion and, through being the one who settled on the land and then proceeded to fortify and defend it against its Traditional Owners, was the one who actually 'conquered' it. This should, however, by no means be taken as evidence that the British military in Australia did not take an active part in the frontier wars. John Connor's book Australian frontier wars, 1788-1838 is specifically concerned with military actions carried out against Aboriginal resistance (Connor 2002).

\section{Implications for protection and interpretation}

Fortified homesteads are significant from a cultural heritage perspective in several ways. First, they are artefacts of the frontier conflict that occurred in their respective regions as a result of colonisation. They speak of the settlers' feelings of vulnerability, paranoia, fear and a 'siege mentality' in occupying someone else's land. They stand testament to the fact that Australia's colonial settlement often progressed in the face of determined Aboriginal resistance. They serve as indisputable physical reminders that the Australian frontier was most certainly not empty, terra nullius, or that Aboriginal people were just decimated by disease or somehow melted away before the advance of European settlement. 
The cultural heritage of the Aboriginal communities in which these sites are located could also benefit from the sites' recognition and preservation as examples of defensive architecture. Similar to the way in which these sites are testaments to the settler's experience of the frontier, they are also memorials or monuments to the Aboriginal resistance.

Unfortunately, however, this perspective has not as yet managed to make its way into the popular mythology or public memory. Currently, the social memory constructing use of these sites is clearly dominated by non-Aboriginal, settler society. Only when all groups and sections of society can come to terms with both (or all) sides of their land's past, and accommodate the telling of more than one story, can that society be said to have reached maturity in terms of its identity.

However, with all of the above points, it is important that the actual interpretation and presentation of these sites be very carefully done. Poor interpretation and presentation could result in these sites reinforcing the old ideas of Aboriginal 'savagery' and the settler as 'victim'. Ideally, their interpretation would present these sites as representing the combined fears and circumstances of both Indigenous communities and settlers in a balanced and sensitive way.

From an architectural heritage standpoint, fortified homesteads are highly significant because they represent a hitherto almost totally omitted aspect of our built heritage- that is, a specifically frontier-influenced modification to Australia's vernacular architecture. Furthermore, compared to non-defensively built civilian structures, surviving examples of fortified homesteads are rare, owing to the majority most likely having been made of a perishable material such as timber. As a result, the need for their recognition and protection is heightened.

\section{Conclusion}

Borne out of a tragic lack of intercultural understanding and coupled with the unstoppable force of colonialism, conflict inevitably erupted wherever the frontier advanced across Australia. Aboriginal peoples who encountered the invaders mounted a guerrilla-style resistance in retaliation to the invaders for transgressing their laws, or to drive them from their Country altogether. The dwellings of the Europeans were attractive targets to Aboriginal warriors, as they contained many sought-after supplies such as food, tools and weapons. There were goods that the Aboriginal people demanded be shared with them in return for what the Europeans had taken: their food, water, land and, often, their women. The Europeans' concept of property, employment and racial superiority caused them to refuse to share, except on their terms only.

So well-known, and in many regions common, were Aboriginal attacks on frontier settlers' buildings that the long-established vernacular architectural styles were modified, if only minimally, in order to respond to the threat. The most common method was the incorporation of one or more embrasures in what would usually be blind walls, as well as in window shutters and doors, in order to provide a means of observing and directing fire upon and attacking Aboriginal warriors from a position of relative cover.

These buildings often passed into local settler society lore based on their defensive construction. Stories associated with them are framed so as to highlight the danger to the settlers and the challenges they overcame, namely 'aggressive' Aboriginal inhabitants, with no consideration of the causes of conflict. In other cases, these buildings' defensive function is actively denied or omitted, likewise serving current settler society's agenda of downplaying frontier conflict.

Rather than being anomalies, in some regions at least, fortified homesteads seem to have been the norm rather than the exception (Kerkhove 2015:8). This is, however, no longer the case, owing to the fact that the earliest frontier buildings were usually constructed in a temporary manner 
of a perishable material such as timber, and therefore few survive. It is argued here that it is important that surviving examples of fortified homesteads be protected owing to their rarity and their role as physical evidence of frontier conflict and Aboriginal resistance.

\section{References}

Allom, R. 1980. A report to the National Trust of Australia (Northern Territory) on the Old Fort, its potential for restoration and recommended action. National Trust, Adelaide.

Altman, J. 2011. A genealogy of 'demand sharing': From pure anthropology to public policy. In Y. Musharbash and M. Barber (eds), Ethnography and the production of anthropological knowledge, pp. 187-200. ANU E Press, Canberra. doi.org/10.22459/epak.03.2011.13.

Armstrong, R.E.M. 1980. The Kalkadoons: A study of an Aboriginal tribe on the Queensland frontier. William Brooks \& Co. Pty Ltd, Brisbane.

Baillie, P. 1972. Port Lincoln sketchbook. Rigby Limited, Adelaide.

Baillie, P. 1978. Port Lincoln and district: A pictorial history. Lynton Publications, Blackwood.

Banks, J. 1970. Kingston flashbacks (Part 1). Ladies Auxiliary of Kingston District Soldiers' Memorial Hospital, Kingston.

Barrowman, A. 1971. Old days and old ways. A.H. Barrowman, Robe.

Bell, P. 1997. Post-colonisation heritage study of Glenthorne CSIRO field station: Report to Janet Gould \& Associates. Historical Research Pty Ltd, Adelaide, South Australia.

Blair St George, R. 1990. Bawns and beliefs: Architecture, commerce and conversion in early New England. Winterthur Portfolio 25(4): 241-287. doi.org/10.1086/496502.

Bonwick, J. 186-. Attack on a settler's hut [picture]. (PIC Drawer 7051 \#T2448 NK1300) National Library of Australia. nla.gov.au/nla.obj-135224743.

Boyd, R. 1961. Australia's home: Its origins, builders and occupiers. Melbourne University Press, Carlton.

Broome, R. 1996. Historians, Aborigines and Australia: Writing the national past. In B. Attwood (ed.), In the age of Mabo: History, Aborigines and Australia, pp. 54-72. Allen \& Unwin, Sydney.

Broome, R. 2005. Aboriginal Victorians: A history since 1800. Allen and Unwin, Crows Nest.

Burke, H., L.A. Wallis, B. Barker, M. Tutty, N. Cole et al. 2017. The homestead as fortress: Fact or Folklore? Aboriginal History 41:151-176. doi.org/10.22459/ah.41.2017.07.

Cannon, M. 1973. Life in the country. Australia in the Victorian Age 2. Thomas Nelson Ltd, Melbourne.

Cantlon, M. 1981. Homesteads of Southern New South Wales 1830-1900. Queensberry Hill Press, Carlton.

Clark, I. 1995. Scars in the landscape: A register of massacre sites in western Victoria, 1803-1859. Aboriginal Studies Press, Canberra.

Connor, J. 2002. The Australian frontier wars, 1788-1838. University of New South Wales Press, Sydney.

Conor, L. 2016. Skin deep: Settler impressions of Aboriginal women. UWA Publishing, Crawley.

Cox, P. and C. Lucas 1978. Australian colonial architecture. Lansdowne Editions, Melbourne.

Cox, P. and W. Stacey 1972. The Australian homestead. Lansdowne Editions, Melbourne.

Croft, J. 1965. Murray Downs. Mid-Murray Illustrated, Swan Hill. 
Crosby, E. 1978. Survey and excavation at Fort Dundas, Melville Island, Northern Territory, 1975. The Australian Society for Historical Archaeology, Sydney.

Curthoys, A. 2003. Constructing national histories. In B. Attwood and S. Foster (eds), Frontier conflict: The Australian experience, pp. 185-200. National Museum of Australia, Canberra.

Denholm, D. 1979. The colonial Australians. Penguin Books Australia, Ringwood.

Dolling, A. 1981. The history of Marion on the Sturt: The story of a changing landscape and its people. Peacock Publications, Frewville.

Durack, M. 1997. Kings in grass castles. Bantam Books, Sydney.

Eyre, E. 1964 (1845). Journals of expeditions of discovery into Central Australia and overland from Adelaide to King George's Sound in the years 1840-1841. First published 1845. Libraries Board of South Australia, Adelaide.

Foote, K. 1997. Shadowed ground: America's landscapes of violence and tragedy. University of Texas Press, Austin.

Forrest, P. 1985. Springvale's story: And early years at the Katherine. Murranji Press, Darwin.

Foster, R., A. Nettelbeck and R. Hosking 2001. Fatal collisions: The South Australian frontier and the violence of memory. Wakefield Press, Kent Town.

Fysh, H. 1933. Taming the north. Angus and Robertson, Sydney.

Gardner, P. 1993. Gippsland massacres: The destruction of the Kurnai Tribes 1800-1860. Ngarak Press, Ensay.

Giles, A. 1870-1885. The first pastoral settlement in the Northern Territory. Manuscript. Private Record Group (PRG 1389/2). State Library of South Australia, Adelaide.

Giles, H. n.d. Memoirs of H.S. Giles (NTRS 298), Folder 1. Manuscript. Northern Territory Archives Service.

Grguric, N. 2007. Fortified homesteads: The architecture of fear in frontier South Australia and the Northern Territory, c. 1847-1885. Unpublished PhD thesis. Flinders University, Adelaide, South Australia.

Grguric, N. 2008. Fortified homesteads: The architecture of fear in frontier South Australia and the Northern Territory, ca. 1847-1885. Journal of Conflict Archaeology 4(1-2):59-85. doi.org/10.1163/ $157407808 \times 382764$.

Haggis, J. 2001. The social memory of a colonial frontier. Australian Feminist Studies 16(34):91-99. doi.org/10.1080/08164640120038944.

Halls, C. 1974. Guns in Australia. Paul Hamlyn, Sydney.

Holthouse, H. 1967. River of gold: The story of the Palmer River gold rush. Angus and Robertson, Sydney.

Kerkhove, R. 2015. Barriers and bastions: Fortified frontiers and white and black tactics. Unpublished paper presented at seminar 'Our shared history: Resistance and reconciliation', Central Queensland University, 11 June.

Lack, C. and H. Stafford 1964. The rifle and the spear. Fortitude Press, Brisbane.

McKernan, M. and M. Browne 1988. Australia: Two centuries of war and peace. Australian War Memorial, Sydney.

Mulvaney, D. 1989 Encounters in place. University of Queensland Press, Brisbane. 
Norris, K. 1976. Australia’s heritage sketchbook. Books For Pleasure, Sydney.

Pedersen, H. and B. Woorunmurra 1995. Jandamarra and the Banuba Resistance. Magabala Books, Broome.

Peterson, N. 1997. Demand sharing: Sociobiology and the pressure for generosity among foragers. In F. Merlan, J. Morton and A. Rumsey (eds), Scholar and sceptic: Australian Aboriginal studies in honour of LR Hiatt, pp. 171-190. Aboriginal Studies Press, Canberra.

Pike, G. 1978. Queensland frontier. Rigby, Hong Kong.

Pikusa, S. 1986. The Adelaide house 1836-1901: The evolution of principal dwelling types. Wakefield Press, Netley.

Police Commissioner 1848a. Letter (GRG 24/6/1848/1156). Correspondence files ('CSO’ files) Colonial, later Chief Secretary's Office. State Records of South Australia, Adelaide.

Police Commissioner 1848b. Letter (GRG 24/6/1848/424). Correspondence files ('CSO' files) - Colonial, later Chief Secretary's Office. State Records of South Australia, Adelaide.

Police Commissioner 1848c. Letter (GRG 24/6/1847/585). Correspondence files ('CSO' files) - Colonial, later Chief Secretary's Office. State Records of South Australia, Adelaide.

Reynolds, H. 1987. Frontier. Allen and Unwin, Sydney.

Reynolds, H. 2013. Forgotten war. NewSouth, Sydney.

Robinson, F. and B. York 1977. The Black Resistance. Widescope, Camberwell.

Roos, F. 1953. Ohio: Architectural cross-road. The Journal of the Society of Architectural Historians 12(2) (May): 3-8. doi.org/10.2307/987538.

Rubertone, P. 1994. Archaeology, colonialism and 17th-century Native America: Towards an alternative interpretation. In R. Layton (ed.), Conflict in the archaeology of living traditions, pp. 33-45.

Routledge, London.

Ryan, L. 1996. The Aboriginal Tasmanians. Allen and Unwin, St Leonards, NSW.

Serle, G. 1977. Manuscripts: Excerpts from the letters of Dr. David Henry Wilsone, squatter, 1839-1841. La Trobe Library Journal 5(19):53-62.

Shakel, P. 2001. Myth, memory, and the making of the American landscape. University Press of Florida, Gainesville.

Smolicz, R.A. and W.W. Sharp 1983. Australia's early dwellings and churches. Angus and Robertson Publishers, London.

Taylor, P. 1988. Station life in Australia, pioneers and pastoralists. Allen and Unwin, Sydney.

Winer, M. 2001. Landscapes, fear and land loss on the nineteenth-century South African colonial frontier. In B. Bender and M. Winer (eds), Contested landscapes: Movement, exile and place, pp. 257-272. Berg, Oxford. doi.org/10.4324/9781003085089-20. 
This text is taken from Archaeological Perspectives on Conflict and Warfare in Australia and the Pacific, edited by Geoffrey Clark and Mirani Litster, published 2022 by ANU Press, The Australian National University, Canberra, Australia.

doi.org/10.22459/TA54.2021.10 